\title{
Problematic alcohol use in Mexican students: Transmission from parents to children
}

\author{
Raquel Mondragón Gómez, ${ }^{1}$ María Elena Medina-Mora lcaza, ${ }^{2,3,4}$ Jorge Ameth Villatoro Velázquez, ${ }^{3,5}$ \\ Marycarmen Bustos Gamiño, ${ }^{5}$ Marcela Tiburcio Sainz, ${ }^{6}$ Emilia Lucio Gómez-Maqueo
}

Programa de Maestría y Doctorado en Psicología, Universidad Nacional Autónoma de México, México. Centro de Investigación en Salud Mental Global, Instituto Nacional de Psiquiatría Ramón de la Fuente Muñiz, México

3 Seminario de Estudios de la Globalidad, Facultad de Medicina, Universidad Nacional Autónoma de México, México.

${ }^{4}$ Dirección de la Facultad de Psicología, Universidad Nacional Autónoma de México, México.

5 Dirección de Investigaciones Epidemiológicas y Psicosociales, Instituto Nacional de Psiquiatría Ramón de la Fuente Muñiz, México

- Departamento de Ciencias Sociales en Salud, Dirección de Investigaciones Epidemiológicas y Psicosociales, Instituto Nacional de Psiquiatría Ramón de la Fuente Muñiz, México

7 Facultad de Psicología, Universidad Nacional Autónoma de México, México.

\section{Correspondence:}

María Elena Medina-Mora lcaza Centro de Investigación en Salud Mental Global, Instituto Nacional de Psiquiatría Ramón de la Fuente Muñiz. Calzada México Xochimilco 101 , Ciudad de México, 14370, México. Phone: +52 55 5655-0185

Email: metmmora@gmail.com

Received: 5 April 2021

Accepted: 30 June 2021

\section{Citation:}

Mondragón Gómez, R., Medina-Mora lcaza, M. E., Villatoro Velázquez, 1. A., Bustos Gamiño, M., Tiburcio Sainz, M., \& Lucio Gómez-Maqueo, E. (2022). Problematic alcohol use in Mexican students: Transmission from parents to children. Salud Mental, $45(1), 19-28$.

DOI: $10.17711 /$ SM.0185-3325.2022.004

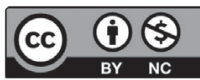

\begin{abstract}
Introduction. Studies in various countries have shown that adolescents with a history of parental use of alcohol have a greater risk of presenting alcohol problems of their own, including binge drinking, driving under the influence of alcohol, and alcohol dependence. A few studies in Mexico have also found this association, but these have been carried out with non-representative populations. Objective. To examine the association between a history of parental alcohol use and binge drinking, and parental use and possible dependence on alcohol, in a national sample of junior high and high school students in Mexico. Method. A descriptive correlational study was carried out based on a secondary analysis of the National Survey of Student Drug Use (Encuesta Nacional de Consumo de Drogas en Estudiantes, ENCODE), which questioned 114,364 respondents. The association was evaluated with an estimate of prevalence ratios $(P R)$. Results. Students whose mothers or both parents used alcohol had a greater risk for binge drinking $(P R[$ mother] $=2.12, p<.001$; $P R$ [both parents $]=2.18, p<.001)$ and possible alcohol dependence $(P R[$ mother $]=5.43, p<.001 ; P R[$ both parents $]=5.14$, $p<.001)$. Those whose fathers alone used alcohol had a lower risk for binge drinking $(P R=1.35, p<.001)$ and for possible dependence $(P R=1.83, p<.001)$. Discussion and conclusion. This study shows differences in the effects of problematic alcohol use by parents: use by the mother or by both parents implies a greater risk of binge drinking and possible dependence for their children. This finding should be considered in the design of interventions to prevent binge drinking.
\end{abstract}

Keywords: Binge drinking, possible dependence, students, parents, intergenerational transmission of alcohol use.

\section{RESUMEN}

Introducción. Diferentes estudios señalan que los adolescentes con antecedentes de consumo parental de alcohol tienen mayor riesgo de presentar problemas de consumo de alcohol como consumo excesivo, manejar bajo los efectos del alcohol y tener dependencia. En México, aunque la investigación también señala una relación positiva, los estudios al respecto son escasos y se han realizado en poblaciones no representativas. Objetivo. Conocer la asociación entre los antecedentes parentales de consumo de alcohol y el consumo excesivo, y entre estos antecedentes y la posible dependencia al alcohol en una muestra nacional de estudiantes de secundaria y bachillerato de México. Método. Se realizó un análisis secundario de la Encuesta Nacional de Consumo de Drogas en Estudiantes, la cual se aplicó a 114,364 estudiantes. Para evaluar la asociación se estimaron los índices de razón de prevalencia $(R P)$. Resultados. Los estudiantes con antecedentes de consumo materno o de ambos padres presentaron mayor riesgo de tener consumo excesivo $(R P$ [mamá] $=2.12, p<.001 ; R P$ [ambos padres] $=2.18, p<.001)$ y posible dependencia al alcohol $(R P$ [mamá] $=5.43, p<.001 ; R P$ [ambos padres] $=5.14, p<.001)$. En tanto, el riesgo de consumo excesivo $(R P=1.35, p<.001)$ o de posible dependencia $(R P=1.83, p<.001)$ fue menor cuando el antecedente era el papá. Discusión y conclusión. Este estudio señala diferencias en el impacto del consumo problemático de alcohol de los padres, de manera que el consumo materno o de ambos padres implica un mayor riesgo de consumo excesivo y de posible dependencia para los estudiantes mexicanos. Este hallazgo debe contemplarse en el diseño de intervenciones dirigidas a prevenir el consumo excesivo de alcohol.

Palabras clave: Consumo excesivo de alcohol, posible dependencia, estudiantes, padres, transmisión intergeneracional del consumo de alcohol. 


\section{INTRODUCTION}

Problems with alcohol or the potential to develop such problems occur within contexts of risk (Medina-Mora, Real, Villatoro, \& Natera, 2013). One of the most important of these contexts is when parents have a problematic alcohol use that children can potentially observe and learn (Yap, Cheong, Zaravinos-Tsakos, Lubman, \& Jorm, 2017). In the United States, one out of four children and adolescents are exposed to alcohol abuse in their family, and approximately 11 million live with an alcohol or drug user (Emshoff \& Price, 1999; Lam \& O'Farrell, 2011; Slutske et al., 2008). In England it is estimated that approximately three million children under 16 live with at least one parent who drinks to excess, almost half a million with a single parent who is a compulsive drinker, 2.6 million with a dangerous drinker, 300,000 with a damaging drinker, and more than 700,000 with a dependent drinker (Manning, 2011). In Mexico, it has been found that approximately $60 \%$ of the adult population age 18-65 has a family history of alcohol use, that is, has a father or mother who drinks frequently or habitually (Natera-Rey, Borges, Medina-Mora, Solis-Rojas, \& Tiburcio-Sainz, 2001). A study in Nuevo Leon found that $80 \%$ of junior high school students in that state had such a history (Armendáriz et al., 2014). A study of adolescents in Tabasco reported that $56.8 \%$ lived with someone who used alcohol, most commonly the father (38.8\%), followed by both parents $(24.5 \%)$, the mother $(13.7 \%)$, and siblings (10.8\%) (Telumbre, López, Sánchez, Magnolia-Araujo, \& Torres, 2017).

Having parents with drinking problems has a variety of implications for the mental health of children and adolescents (Rossow, Keating, Felix, \& McCambridge, 2016). Prominent among these is that adolescents have a greater probability of using alcohol or developing related problems than children of parents who do not drink. This phenomenon is referred to broadly as intergenerational transmission of alcohol use (Campbell \& Oei, 2010), which can be described as the spectrum of behaviors and characteristics related to the use of alcohol from one generation to another (Branje et al., 2020).

A number of studies have examined intergenerational transmission in the Mexican context. Using data from the 1988 National Addiction Survey (Encuesta Nacional de Adicciones, ENA), Natera-Rey et al. (2001) found that adult men with a family history of alcohol use had twice the probability of developing dependency, and women a $27 \%$ greater probability than those without such a history. In a study of students, Hernández (2014) found a positive and significant relationship $\left(r_{\mathrm{s}}=.214, p<.001\right)$ between a family history of alcohol use and personal use among 256 students in the state of Tabasco. Among the significant findings in this study was that the prevalence of ever having used alcohol and that of having used it in the previous month differed according to family history $\left(\chi^{2}=13.04, p=.001 ; \chi^{2}=7.32, p=.007\right.$, respectively). Armendáriz et al. (2014), in a study of 680 university students in the state of Nuevo Leon, found that a family history of alcohol use influenced the students' own use $(B=.080, p=.001)$. A subsequent study, with 240 high school students in the same state, found that greater alcohol use by parents was associated with an increased use by their children $\left(r_{\mathrm{s}}=.196 ; p<.01\right)$ (Armendáriz et al., 2015). A study of 178 junior high school students in Campeche found a positive and significant relationship between family history of alcohol use and cumulative AUDIT score $\left(r_{\mathrm{s}}=.164\right.$, $p=.025)$, and also between that history and the number of alcoholic beverages the participants consumed $\left(r_{\mathrm{s}}=.181\right.$, $p=.005$ ) (Telumbre et al., 2017).

More extensive international research has found that adolescents whose parents have problems with alcohol use begin to drink at earlier ages than others (Donovan \& Molina, 2011; Capaldi, Tiberio, Kerr, \& Pears, 2016). They also drink greater quantities of alcohol (Bailey, Hill, Oesterle, \& Hawkins, 2006; Alati et al., 2014) and with greater frequency (Oshi et al., 2018; Hernández, 2014). A history of parental alcohol use has also been related with patterns of use that have major consequences for adolescent health. For example, the children of drinkers report more binge drinking (Pedersen \& von Soest, 2013), have more episodes of alcohol intoxication (Latendresse at al., 2008; Haugland, Holmen, Rayndal, \& Bratberg, 2013; García-Barba, Giménez-García, Castro-Calvo, Nebot-García, \& Ballester-Arnal, 2018), and develop alcohol use disorder more frequently than children of non-drinkers (Meyers et al., 2014; Natera-Rey et al., 2001; Telumbre et al., 2017; Murphy, O'Sullivan, O’Donovan, Hope, \& Davoren, 2016; Guo, Hawkins, Hill, \& Abbot, 2001; Poelen, Engels, Scholte, Boomsma, \& Willemsen, 2009).

The effect of parental alcohol use on adolescents seems to differ according to the sex of the parent, but the evidence is not clear so far. Some authors have reported that fathers' drinking, but not mothers', predicts adolescent children's alcohol use (Handley \& Chassin, 2009; Mares, van der Vorst, Engels, \& Lichtwarck-Aschoff, 2011; Murphy et al., 2016). However, MacLeod et al. (2008) and Poelen, Scholte, Willemsen, Boomsma, and Engels (2007) found that mothers' drinking or problems with alcohol have a greater impact. Methodological problems have difficulted the identification of these variations. Some studies collapse alcohol use by mothers and fathers into a single variable (Armstrong et al., 2013; Hernández, 2014; Pedersen \& von Soest, 2013; Telumbre, 2017), while others only examine drinking by one parent (Alati et al., 2008; Cortes, Fleming, Mason, \& Catalano, 2009). This latter difficulty is noted by Branje et al. (2020), who find that most studies of intergenerational transmission have included only one individual per generation, even though the children affected share genes with both of their parents. 
Differences in the effects of fathers' and mothers' drinking might be related to a number of factors. One of these is that parents and children share environments and other characteristics that increase or decrease the association between the alcohol use of each (Branje et al., 2020). These variations could be emphasized by cultural differences in parental roles in different countries. Most studies have been conducted in the U.S., Australia, and England, and those conducted in Mexico have not explored differences related to the sex of the parent, except for that of Natera-Rey et al. (2001). The evidence for Mexico is also limited because the study populations have not been representative, and the majority of statistical analyses used have been univariate. Most international and Mexican studies have been based on non-probabilistic samples, which include only participants living in a particular region (Alati et al., 2014; Donovan \& Molina, 2011; Haugland et al., 2013; Kovacs et al., 2008; MacLeod et al., 2008), who have a certain socioeconomic status (Capaldi et al., 2016; Casswell, Pledger, \& Pratap, 2002), who live in areas with high crime rates (Bailey et al., 2006; Capaldi et al., 2016), or who are students from the same school (Armendáriz et al., 2015; Hernández, 2014). The nature of these samples limits the possible generalization of the results.

Analysis of the variations in this phenomenon is fundamental to strengthen research on the psychosocial mechanisms of intergenerational transmission. It can aid in the development of preventive interventions for alcohol use in children of drinkers, and also to motivate public policy regarding the consequences of alcohol use. For this reason, it is important to have evidence about the relationship between parents' and children's alcohol consumption that is based on a nationally representative sample. The objective of this study is thus to evaluate the association between the alcohol use of students and their perceptions of their parents' drinking, using a random national sample.

\section{METHOD}

\section{Study design}

This is a secondary analysis of the National Survey of Student Drug Use (Encuesta Nacional de Consumo de Drogas en Estudiantes, ENCODE), which questioned 114,364 respondents (see Villatoro et al., 2015 for additional details about the survey).

\section{Subjects}

The ENCODE was carried out in 2014 with a random, representative, stratified, systematic cluster sampling of junior high and high school students from the 32 states of Mexico, including nine cities. The sample size was estimated consid- ering the non-response rate of $20 \%$ found in previous studies and various reasons for the non-responses. The confidence level of the sample is $95 \%$, with an average absolute error of .004 and a design effect of 2 . The sample was weighted by group, educational level, and state in order to perform the estimation and analyze the data. The estimated sample included 127,920 respondents, with 1,560 in each stratum (a total of 4,680 per state) and 1,560 per stratum in each of the cities (a total of 4,680 per city). The final sample included 114,364 respondents, with a non-response rate of $10.6 \%$ (reflecting administrators or students who declined to participate). These were divided between 57,402 junior high school students with a non-response rate of $10.3 \%$ and 56,962 high school students with a non-response rate of $10.9 \%$.

\section{Measurements}

Binge drinking refers to five or more drinks on a single occasion during the 30 days prior to the study. It was evaluated with the question "How often have you had five or more drinks of any alcoholic beverage on a single occasion?"

Possible dependence on alcohol. Dependence implies a series of behavioral, cognitive, or physiological phenomena that can appear after repeated alcohol use. It includes symptoms such as an intense craving for a drink, difficulty in controlling drinking, and continued drinking in spite of the consequences. It was evaluated with the Alcohol Use Disorders Identification Test (AUDIT) (Babor, Higgins-Biddle, Saunders, \& Monteiro, 2001); a score of 2040 was considered a case of possible dependence (Babor \& Robaina, 2016).

Problematic parental use of alcohol refers to students' perception of their parents' behavior related to alcohol. It was evaluated with two questions: "Do you believe your father has problems related to his use of alcohol?" and "Do you believe your mother has problems related to her use of alcohol?" For analysis purposes, these questions were grouped under a variable "Problematic parental use of alcohol," which was assigned a value of 0 if neither parent had a problem with the use of alcohol (NPA), 1 if the father had a problem with the use of alcohol (FPA), 2 if the mother had a problem with the use of alcohol (MPA), and 3 if both parents had a problem with the use of alcohol (BPA).

Sociodemographic variables: Sex (female, male), level of study (junior high, high school), perceived socioeconomic level (low, medium low, medium, medium high, high), type of community (urban, rural), enrollment status (full-time, part-time), employment status (not working, working), father's education (elementary school or less, junior high school or more), mother's education (elementary school or less, junior high school or more), and indigenous language (student or family member speaks an indigenous language, neither student nor family members speak an indigenous language). 
Table 1

Percentage with Parental History of Alcohol Use and Sociodemographic Characteristics

\begin{tabular}{|c|c|c|c|c|c|c|c|c|c|}
\hline & \multicolumn{3}{|c|}{ Girls } & \multicolumn{3}{|c|}{ Boys } & \multicolumn{3}{|c|}{ Total } \\
\hline & $n$ & $N$ & $\%$ & $n$ & $N$ & $\%$ & $n$ & $N$ & $\%$ \\
\hline \multicolumn{10}{|l|}{ Parents' problematic alcohol use } \\
\hline None (NPA) & 49,885 & $4,542,105$ & 86.5 & 48,308 & $4,490,772$ & 86.3 & 98,193 & $9,032,877$ & 86.4 \\
\hline Father (FPA) & 6,321 & 553,340 & 10.5 & 6,050 & 550,651 & 10.6 & 12,371 & $1,103,991$ & 10.6 \\
\hline Mother (MPA) & 826 & 68,968 & 1.3 & 814 & 70,685 & 1.4 & 1,640 & 139,653 & 1.3 \\
\hline Both (BPA) & 1,051 & 85,418 & 1.6 & 1,109 & 93,875 & 1.8 & 2,160 & 179,293 & 1.7 \\
\hline \multicolumn{10}{|l|}{ Sex } \\
\hline Female & & & & & & & 58,083 & $5,249,831$ & 50.2 \\
\hline Male & & & & & & & 56,281 & $5,205,983$ & 49.8 \\
\hline \multicolumn{10}{|l|}{ School level } \\
\hline Junior high & 28,825 & $3,225,676$ & 61.4 & 28,577 & $3,275,978$ & 62.9 & 57,402 & $6,501,654$ & 62.2 \\
\hline High school & 29,258 & $2,024,155$ & 38.6 & 27,704 & $1,930,005$ & 37.1 & 56,962 & $3,954,160$ & 37.8 \\
\hline \multicolumn{10}{|l|}{ Perceived socioeconomic level } \\
\hline Low & 11,289 & $1,028,900$ & 21.0 & 8,843 & 813,165 & 16.8 & 20,132 & $1,842,065$ & 18.9 \\
\hline Medium low & 11,016 & $1,002,065$ & 20.5 & 10,180 & 935,263 & 19.3 & 21,196 & $1,937,328$ & 19.9 \\
\hline Medium & 10,234 & 927,323 & 19.0 & 10,450 & 967,876 & 20.0 & 20,684 & $1,895,199$ & 19.5 \\
\hline Medium high & 10,784 & 997,163 & 20.4 & 11,662 & $1,095,414$ & 22.6 & 22,446 & $2,092,577$ & 21.5 \\
\hline High & 10,399 & 933,344 & 19.1 & 11,013 & $1,024,710$ & 21.2 & 21,412 & $1,958,055$ & 20.1 \\
\hline \multicolumn{10}{|l|}{ Type of community } \\
\hline Rural & 6,068 & 778,616 & 14.8 & 6,299 & 804,958 & 15.5 & 12,367 & $1,583,574$ & 15.1 \\
\hline Urban & 52,015 & $4,471,215$ & 85.2 & 49,982 & $4,401,025$ & 84.5 & 101,997 & $8,872,240$ & 84.9 \\
\hline \multicolumn{10}{|l|}{ Student status } \\
\hline Full-time & 46,566 & $4,198,341$ & 81.2 & 43,318 & $3,996,550$ & 78.2 & 89,884 & $8,194,892$ & 79.7 \\
\hline Not in school & 10,448 & 970,537 & 18.8 & 11,864 & $1,116,178$ & 21.8 & 22,312 & $2,086,715$ & 20.3 \\
\hline \multicolumn{10}{|l|}{ Employment status } \\
\hline Not working & 49,258 & $4,435,957$ & 85.7 & 39,397 & $3,606,054$ & 70.6 & 88,655 & $8,042,011$ & 78.2 \\
\hline Working & 7,932 & 741,160 & 14.3 & 15,849 & $1,502,519$ & 29.4 & 23,781 & $2,243,679$ & 21.8 \\
\hline \multicolumn{10}{|l|}{ Father's education } \\
\hline Junior high or more & 39,266 & $3,450,715$ & 72.0 & 39,139 & $3,517,159$ & 74.4 & 78,405 & $6,967,874$ & 73.2 \\
\hline Elementary school or less & 13,684 & $1,339,965$ & 28.0 & 12,203 & $1,209,941$ & 25.6 & 25,887 & $2,549,907$ & 26.8 \\
\hline \multicolumn{10}{|l|}{ Mother's education } \\
\hline Junior high or more & 40,337 & $3,509,946$ & 71.1 & 40,095 & $3,581,344$ & 74.0 & 80,432 & $7,091,290$ & 72.6 \\
\hline Elementary school or less & 14,454 & $1,423,568$ & 28.9 & 12,533 & $1,258,098$ & 26.0 & 26,987 & $2,681,665$ & 27.4 \\
\hline \multicolumn{10}{|l|}{ Type of community } \\
\hline Indigenous community & 6,165 & 583,716 & 11.1 & 6,378 & 608,249 & 11.7 & 12,543 & $1,191,965$ & 11.4 \\
\hline Not indigenous community & 51,918 & $4,666,115$ & 88.9 & 49,903 & $4,597,734$ & 88.3 & 101,821 & $9,263,849$ & 88.6 \\
\hline
\end{tabular}

Note: $n=$ Non-weighted frequency of respondents.

\section{Procedure}

School authorities were asked for their permission to conduct the survey, and for survey personnel to do so in the classroom. The objectives of the study were explained to the students, and they were told that their response was vol- untary, anonymous, and confidential. The anonymity and confidentiality of self-administered surveys, carried out in groups without identifying individual participants, encourages freer and more truthful responses (Harrison \& Hughes, 1997; Medina-Mora, Gómez-Mont, \& Campillo, 1981). The survey was administered in classroom groups, with an 
Table 2

Prevalence Ratios of Binge Drinking, History of Parental Alcohol Use, and Sociodemographic Variables

\begin{tabular}{|c|c|c|c|c|c|c|c|}
\hline & \multicolumn{7}{|c|}{ Binge drinking } \\
\hline & $n$ & $N$ & $\%$ & $X^{2}$ & $P R$ & $95 \% \mathrm{Cl}$ & $p$ \\
\hline \multicolumn{8}{|l|}{ Parents' problematic alcohol use } \\
\hline None (NPA) & 13,901 & $1,190,706$ & 13.2 & $1507.8^{*}$ & 1 & & \\
\hline Father (FPA) & 2,491 & 216,252 & 19.6 & & 1.35 & $1.27-1.43$ & .001 \\
\hline Mother (MPA) & 622 & 48,566 & 34.8 & & 2.12 & $1.94-2.32$ & .001 \\
\hline Both (BPA) & 749 & 61,296 & 34.2 & & 2.18 & $2.01-2.37$ & .001 \\
\hline \multicolumn{8}{|l|}{ Sex } \\
\hline Female & 8,295 & 699,602 & 13.3 & $129.7^{*}$ & 1 & & \\
\hline Male & 9,468 & 817,217 & 15.7 & & 1.11 & $1.06-1.17$ & .001 \\
\hline \multicolumn{8}{|l|}{ School level } \\
\hline Junior high & 4,559 & 559,368 & 8.6 & $5283.7^{*}$ & 1 & & \\
\hline High school & 13,204 & 957,451 & 24.2 & & 2.62 & $2.42-2.84$ & .001 \\
\hline \multicolumn{8}{|l|}{ Perceived socioeconomic level } \\
\hline Low & 3,074 & 256,111 & 13.9 & $55.2^{*}$ & 1 & & \\
\hline Medium low & 3,273 & 274,754 & 14.2 & & 1.03 & $.96-1.10$ & .329 \\
\hline Medium & 3,188 & 276,887 & 14.6 & & 1.10 & $1.03-1.18$ & .004 \\
\hline Medium high & 3,396 & 300,934 & 14.4 & & 1.11 & $1.03-1.19$ & .002 \\
\hline High & 3,744 & 317,229 & 16.2 & & 1.27 & $1.19-1.36$ & .001 \\
\hline \multicolumn{8}{|l|}{ Type of community } \\
\hline Rural & 1,366 & 153,453 & 9.7 & $382.07^{*}$ & 1 & & \\
\hline Urban & 16,397 & $1,363,366$ & 15.4 & & 1.15 & $1-1.31$ & .037 \\
\hline \multicolumn{8}{|l|}{ Student status } \\
\hline Full-time & 13,466 & $1,148,522$ & 14 & $93.07^{*}$ & 1 & & \\
\hline Not in school & 3,991 & 345,015 & 16.5 & & 1.13 & $1.07-1.19$ & .001 \\
\hline \multicolumn{8}{|l|}{ Employment status } \\
\hline Not working & 12,153 & $1,040,725$ & 12.9 & $816.8^{*}$ & 1 & & \\
\hline Working & 5,346 & 453,504 & 20.2 & & 1.47 & $1.41-1.54$ & .001 \\
\hline \multicolumn{8}{|l|}{ Father's education } \\
\hline Junior high or more & 12,656 & $1,061,873$ & 15.2 & $41.4^{*}$ & 1 & & \\
\hline Elementary school or less & 3,860 & 347,773 & 13.6 & & 1.01 & $.96-1.06$ & .600 \\
\hline \multicolumn{8}{|l|}{ Mother's education } \\
\hline Junior high or more & 13,152 & $1,097,211$ & 15.5 & $95.3^{*}$ & 1 & & \\
\hline Elementary school or less & 3,877 & 351,164 & 13.1 & & .94 & $.88-.99$ & .043 \\
\hline \multicolumn{8}{|l|}{ Speaks indigenous language } \\
\hline Participant or family member & 1,571 & 142,183 & 11.9 & $78.9^{*}$ & 1 & & \\
\hline Neither participant nor family member & 16,192 & $1,374,636$ & 14.8 & & 1.13 & $1.05-1.23$ & .001 \\
\hline
\end{tabular}

average duration of 70 minutes. The questionnaires were sent for coding and data entry in locations used to consolidate the results. Data entry was performed using intelligent software for response consistency developed in a visual programming environment.

\section{Ethical Considerations}

The project was approved by the Research Ethics Committee of the Ramón de la Fuente Muñiz National Institute of Psychiatry (Instituto Nacional de Psiquiatría Ramón de la Fuen- 
te, INPRFM) (Approval No. CEI/C/020/2014). Students' participation was voluntary, and they were informed that they could decide to stop answering questions at any time.

\section{Statistical analysis}

A univariate chi-square analysis was first conducted to analyze the association between parental use of alcohol, socioeconomic predictors, and students' binge drinking and possible dependence. For the multiple analysis, the different predictors were considered simultaneously, using the estimation of prevalence ratios (PR) based on generalized linear models (GLM) with log link and binomial distribution, including only those students who responded all the variables analyzed $(n=91,901)$. All analyses modeled the sample design of the study and were carried out with Stata statistical software (Version 13).

\section{RESULTS}

\section{Participant characteristics}

Of the total 114,364 students surveyed, $52 \%$ were female, of whom $61.4 \%$ were junior high school students and $14.3 \%$ also worked; $21 \%$ reported a low and $19.1 \%$ a high socioeconomic level. The majority (85.2\%) lived in urban areas, and $11.1 \%$ spoke an indigenous language or lived in a household where one was spoken. Of the males, $62.9 \%$ were junior high school students and $29.4 \%$ also worked; $22.6 \%$ reported a socioeconomic level of medium to medium-high, $84.5 \%$ lived in urban areas, and $11.7 \%$ spoke an indigenous language or lived in a household where one was spoken (Table 1).

\section{History of parents' problematic alcohol use}

Of the students responding to the survey, $10.6 \%$ believed their father had problems with alcohol use, $1.3 \%$ believed that their mother did, and $1.7 \%$ believed that both parents did (Table 1). These numbers were practically identical between boys and girls.

\section{Parental alcohol use and binge drinking}

Of the students who believed one or both of their parents had a problematic alcohol use, $19.6 \%$ of those who believed it of the father (FPA), $34.8 \%$ of those who believed it of the mother (MPA), and $34.2 \%$ of those who believed it of both parents (BPA), reported binge drinking of their own in the previous month (Table 2). The prevalence ratio analysis found that those in the MPA group had twice the risk for binge drinking $(P R=2.12$; 95\% CI $[1.94,2.32])$ as those without parents with problematic use (NPA), and they also showed a greater risk than those in the FPA group. Those in the BPA group also had twice the risk for binge drinking as those in the NPA group $(P R=2.18 ; 95 \%$ CI [2.01, 2.37]). Those in the FPA group had a $35 \%$ greater risk for binge drinking (Table 2).

The analyses also showed that being in high school was the sociodemographic characteristic most associated with students' binge drinking ( $P R=2.62 ; 95 \%$ CI $[2.42,2.84])$, and that boys, those with jobs, and those at medium-high and high socioeconomic levels showed a greater risk for binge drinking (Table 2).

\section{Parental alcohol use and students' possible alcohol dependence}

Possible dependence was found in $2.6 \%$ of students in the FPA group, $8.2 \%$ in the MPA group, and $8 \%$ in the BPA group (Table 3). The prevalence ratio analysis showed a risk of possible dependence that was $83 \%$ greater in the FPA group $(P R=1.83 ; 95 \%$ CI $[1.59,2.27])$, and four times greater in the MPA group $(P R=5.43 ; 95 \%$ CI $[4.20,7.03])$ and in the BPA group $(P R=5.14 ; 95 \%$ CI $[3.99,6.62])$ than in the NPA group. The risk of possible dependence was also greater in the MPA than in the FPA group (Table 3). In addition to these relationships with parental alcohol use, high school students, students with jobs, those with a high socioeconomic level, boys, and those who were not studying full-time had greater risk for possible dependence (Table 3).

\section{DISCUSSION AND CONCLUSION}

The prevalence of parental alcohol use found in this study was less than that reported for other countries, where the frequency of hazardous consumption ranges from $16 \%$ to $25 \%$ in fathers and $5 \%$ to $13 \%$ in mothers (Haugland et al., 2013; Lieb et al., 2002; McManus, Bebbington, Jenkins, \& Brugha, 2016; Ohannessian, 2012; Torvik, Rognmo, Ask, Røysamb, \& Tambs, 2011). The estimations in the current study are closest to those of McManus et al. (2016) and Torvik et al. (2011), who found harmful use among approximately $2 \%$ of mothers. This comparison should be taken with caution, as the indicators those authors used (dangerous and harmful use, as measured with the AUDIT) are different than the method of measuring parental alcohol use employed in our study.

In comparison to other studies in Mexico, our results are similar to those of Telumbre et al. (2017) for junior high school students from Campeche, where $10.8 \%$ of the participants reported having a father who drank once a week to the point of being drunk and $1.4 \%$ reported having a mother who did so. Armendáriz et al. (2014), who studied university students in Nuevo Leon, found higher percentages: approximately $40 \%$ of their respondents had a history of 
Table 3

Prevalence Ratios of Possible Dependence on Alcohol, History of Parental Alcohol Use, and Sociodemographic Variables

\begin{tabular}{|c|c|c|c|c|c|c|c|}
\hline & \multicolumn{7}{|c|}{ Possible Dependence } \\
\hline & $n^{*}$ & $N$ & $\%$ & $X^{2}$ & $P R$ & $95 \% \mathrm{Cl}$ & $p$ \\
\hline \multicolumn{8}{|l|}{ Parents' problematic alcohol use } \\
\hline None (NPA) & 1,276 & 113,412 & 1.3 & $1084.8^{*}$ & 1.00 & & \\
\hline Father (FPA) & 343 & 28,168 & 2.6 & & 1.83 & $1.59-2.27$ & .001 \\
\hline Mother (MPA) & 143 & 11,476 & 8.2 & & 5.43 & $4.20-7.03$ & .001 \\
\hline Both (BPA) & 181 & 14,374 & 8 & & 5.14 & $3.99-6.62$ & .001 \\
\hline \multicolumn{8}{|l|}{ Sex } \\
\hline Female & 754 & 64,597 & 13.3 & $100.6^{*}$ & 1.00 & & \\
\hline Male & 1,189 & 101,833 & 15.7 & & 1.35 & $1.17-1.57$ & .001 \\
\hline \multicolumn{8}{|l|}{ School level } \\
\hline Junior high & 524 & 65,866 & 1 & $413.5^{\star}$ & 1.00 & & \\
\hline High school & 1,419 & 101,565 & 2.6 & & 2.36 & $1.97-2.83$ & .001 \\
\hline \multicolumn{8}{|l|}{ Perceived socioeconomic level } \\
\hline Low & 348 & 26,704 & 1.5 & $17.9^{* *}$ & 1 & & \\
\hline Medium low & 329 & 27,620 & 1.4 & & .98 & $.75-1.27$ & .907 \\
\hline Medium & 333 & 32,514 & 1.7 & & 1.21 & $.95-1.52$ & .107 \\
\hline Medium high & 367 & 32,397 & 1.5 & & 1.19 & $.93-1.51$ & .152 \\
\hline High & 444 & 36,314 & 1.9 & & 1.45 & $1.15-1.84$ & .002 \\
\hline \multicolumn{8}{|l|}{ Type of community } \\
\hline Rural & 138 & 13,680 & .9 & $70.1^{*}$ & 1 & & \\
\hline Urban & 1,805 & 153,750 & 1.7 & & 1.42 & $1.07-1.90$ & .015 \\
\hline \multicolumn{8}{|l|}{ Student status } \\
\hline Full-time & 1,367 & 118,904 & 1.5 & $69.6^{*}$ & 1 & & \\
\hline Not in school & 538 & 46,539 & 2.2 & & 1.34 & $1.13-1.60$ & .001 \\
\hline \multicolumn{8}{|l|}{ Employment status } \\
\hline Not working & 1,146 & 98,643 & 1.2 & $357.03^{*}$ & 1 & & \\
\hline Working & 764 & 65,942 & 2.9 & & 2.00 & $1.72-2.33$ & .001 \\
\hline \multicolumn{8}{|l|}{ Father's education } \\
\hline Junior high or more & 1,367 & 115,696 & 1.7 & 1.16 & 1 & & \\
\hline Elementary school or less & 435 & 39,899 & 1.6 & & 1.11 & $.92-1.33$ & .270 \\
\hline \multicolumn{8}{|l|}{ Mother's education } \\
\hline Junior high or more & 1,455 & 122,641 & 1.7 & $19.4^{*}$ & 1 & & \\
\hline Elementary school or less & 398 & 36,091 & 1.3 & & .83 & $.68-1.01$ & .067 \\
\hline \multicolumn{8}{|l|}{ Speaks indigenous language } \\
\hline Participant or family member & 228 & 18,471 & 1.6 & .252 & 1 & & \\
\hline Neither participant nor family member & 1,715 & 148,959 & 1.6 & & .94 & $.74-1.19$ & .634 \\
\hline
\end{tabular}

Notes: $n=$ Non-weighted frequencies of persons with possible dependency. $N=$ Expanded population with possible dependency. ${ }^{*} p<.05 ;{ }^{* *} p<.001$

family alcohol use. These differences between international and Mexican estimates could be explained by one of the following reasons: 1 . some measures combine the alcohol consumption of both parents, resulting in higher prevalence rates; 2 . the measure of family history of alcohol use in the
Mexican studies is based on frequent use, not necessarily problematic use, and may therefore be an overestimation; 3. some studies measure the volume or frequency of use, and others, including the present study, use methods based on children's perceptions; 4. another factor that may con- 
tribute to the discrepancies could be cultural differences in the way alcohol is consumed: in some countries, including Mexico, drinking by women may pass unnoticed, or it may be part of traditions where it is not seen as problematic; and 5. reporting of alcohol use could be greater among older respondents: parents could use alcohol more openly in front of adult children such as university students.

One of the main findings of the current study is that students with a history of parental alcohol use have a greater risk for binge drinking and possible dependence than those whose parents did not have problems with alcohol use, which provides evidence for the intergenerational transmission of alcohol use in the Mexican population. The effect is similar to that reported in other studies. The values obtained in the PR analysis are close to those reported in studies in other countries (Alati et al., 2014; Capaldi et al., 2016; Maldonado, Reingle, Delcher, \& Branchini, 2011; MacLeod et al., 2008; Murphy et al., 2016). The values reflecting the development of dependence in males with family histories of alcohol use are similar to other studies in Mexico, although the latter evaluated adults (Natera-Rey et al., 2001). The comparison of similarities and differences between these studies is complicated by their use of different statistical measures, but the direction of the results is similar.

Our results support the hypothesis that the effect of parental use of alcohol is different for fathers and mothers. We found that problematic use by mothers is associated with a greater risk of binge drinking and possible dependence by students, similar to the findings in other studies (Haugland et al., 2013; Capaldi at al., 2016). These differences could be related to the fact that mothers' use of alcohol affects different variables than fathers,' namely the care and raising of children (Rognmo, Torvik, Ask, Røysamb, \& Tambs, 2012; Haugland et al., 2013) and family organization and cohesion (Jester, Jacobson, Sokol, Tuttle, \& Jacobson, 2000). Children spend more time with their mothers, so that mothers provide a closer behavioral model than fathers (Capaldi et al., 2016). The use of alcohol by women is also accompanied by increased depression and less emotional availability for their children (El-Sheikh \& Flanagan, 2001).

\section{Limitations and advantages of the study}

One of the limitations of this study is that the variable measuring parents' alcohol use is based on the perceptions of their children, and this type of measurement involves various biases. Parental alcohol consumption could be underestimated because children and adolescents living with drinkers may sometimes normalize its use and consequences, and may even have positive expectations about its use (Voogt et al., 2017; Suárez, Del Moral, Martínez, John, \& Musitu, 2016). This form of measurement may also lead to an underestimate of mothers' alcohol use: in some Mexican homes, women hide their drinking (Fernández \& Corral,
2018; Gómez, 2006). Fathers' drinking, on the other hand, may be overestimated, since the problematic use of alcohol by men manifests itself in behavior that is more visible to children (Ramírez, Naal, Salinas, \& Pérez, 2014). The underestimation of parental use of alcohol may lead to an underestimation of the effects of a history of parental use on students' own alcohol use (Haugland et al., 2013).

The strengths of this study lie in the internal validity of the results, given that the sample was randomly selected. As it is nationally representative, it can therefore be generalized to the population of junior high and high school students throughout Mexico.

\section{Implications}

Although the percentages of parental use of alcohol are low, we found that the variables of alcohol use by mothers and by both parents were those that showed the greatest association with binge drinking and possible dependence in children. Our findings suggest the need to: 1. identify women in addiction treatment centers who are mothers of children and adolescents; 2. provide conditions that facilitate their adherence to treatment (for example, by providing spaces for the care of children); 3. provide interventions with a gender perspective; and 4. integrate children into intervention plans. In addition, men's participation in women's treatment should be seen as an opportunity to strengthen their participation in the care and raising of their children, which could in itself contribute to the success of alcohol interventions (Bell, Herring, \& Annand, 2020; Huxley \& Foulger, 2008).

The findings of our study suggest the importance of continued investigation of this topic with more detailed measurement of parents' use, for example, of the length of time they have had problematic use. It would also be useful to carry out qualitative studies to examine the different effects of problematic use by mothers and fathers on the mental health of adolescents.

Our findings also provide important evidence for the intergenerational transmission of alcohol use in Mexico, which has implications for the physical and emotional health of Mexican students and the economic costs to society as a whole. Further research should evaluate the effects of mothers' and fathers' alcohol use on different environmental variables identified in the international literature as possible mediators, including family cohesion, interactions, and functionality, as well as child-raising skills. It should also investigate the relationship between parents' alcohol use and different understandings about alcohol use among adolescents, such as expectations about drinking, the perception of risk, and reasons for drinking, which would help to support a cognitive model of intergenerational transmission of alcohol use (Campbell \& Oei, 2010). Further research on this topic in Mexico would strengthen programs 
for the prevention and treatment of alcohol use. Prevention should include selective, indicated actions in family, community, and school environments, with children of drinkers identified as a high-risk population.

\section{Funding}

The ENCODE was developed with funding from the National Center for the Prevention and Control of Addictions (Centro Nacional para la Prevención y Control de las Adicciones, CENADIC) and the Secretary of Health.

\section{Conflict of interest}

The authors declare that they have no conflicts of interest.

\section{Acknowledgements}

We are grateful to the National Council on Science and Technology (Consejo Nacional de Ciencia y Tecnología, CONACYT), which provided a doctoral scholarship to the first author (CVU: 548398). We also thank the conceptual design and sample control team, the training team, and the surveying and fieldwork supervision team for their hard work in carrying out the ENCODE (2014). We are also grateful to Itzia Sayuri Soto Hernández for her assistance in the development of this project. Finally, we thank the students who participated in the survey.

\section{REFERENCES}

Alati, R., Baker, P., Betts, K. S., Connor, J. P., Little, K., Sanson, A., \& Olsson, C. A. (2014). The role of parental alcohol use, parental discipline and antisocial behaviour on adolescent drinking trajectories. Drug and Alcohol Dependence, 134, 178-184. doi: 10.1016/j.drugalcdep.2013.09.030

Alati, R., Clavarino, A., Najman, J. M., O'Callaghan, M., Bor, W., Al Mamun, A., \& Williams, G. M. (2008). The developmental origin of adolescent alcohol use: Findings from the Mater University Study of Pregnancy and its outcomes. Drug and Alcohol Dependence, 98(1-2), 136-143. doi: 10.1016/j. drugalcdep.2008.05.011

Armendáriz, N., Almanza, J., de Jesús Alonso-Castillo, M. T., Oliva-Rodríguez, N. N., Alonso-Castillo, M. M., \& López-Cisneros, M. A. (2015). La historia familiar y la conducta de consumo de alcohol como factor sociocultural en el adolescente. Perspectiva de enfermeria. Aquichan, 15(2), 219-227. doi: 10.5294/aqui.2015.15.2.6.

Armendáriz, N., Alonso,M, Alonso, B.,López, M., Rodríguez, L., \& Méndez, M. (2014). La familia y el consumo de alcohol en estudiantes universitarios. Ciencia y Enfermería, 20(3), 109-118. doi: 10.4067/S0717-95532014000300010

Armstrong, J. M., Ruttle, P. L., Burk, L. R., Costanzo, P. R., Strauman, T. J., \& Essex, M. J. (2013). Early risk factors for alcohol use across high school and its covariation with deviant friends. Journal of Studies on Alcohol and Drugs, 74(5), 746-756. doi: 10.15288/jsad.2013.74.746

Babor, T. F., Higgins-Biddle, J. C., Saunders, J. B., \& Monteiro, M. G. (2001). Cuestionario de Identificación de los Trastornos debidos al Consumo de Alcohol. Madrid: Organización Mundial de la Salud y Generalitat Valenciana.

Babor, T., \& Robaina, K. (2016). The Alcohol Use Disorders Identification Test (AUDIT): A review of graded severity algorithms and national adaptations. The International Journal of Alcohol and Drug Research, 5(2), 17-24. doi: 10.7895/ ijadr.v5i2.222

Bailey, J. A., Hill, K. G., Oesterle, S., \& Hawkins, J. D. (2006). Linking substance use and problem behavior across three generations. Journal of Abnormal Child Psychology, 34(3), 263-282. doi: 10.1007/s10802-006-9033-z

Bell, L., Herring, R., \& Annand, F. (2020). Fathers and substance misuse: a literature review. Drugs and Alcohol Today, 20(4), 353-369. doi: 10.1108/DAT-06-20200037
Branje, S., Geeraerts, S., de Zeeuw, E. L., Oerlemans, A. M., Koopman-Verhoeff, M. E., Schulz, S., ... Boomsma, D. I. (2020). Intergenerational transmission: Theoretical and methodological issues and an introduction to four Dutch cohorts. Developmental Cognitive Neuroscience, 45, 100835. doi: 10.1016/j. den.2020.100835

Campbell, J. M., \& Oei, T. P. (2010). A cognitive model for the intergenerational transference of alcohol use behavior. Addictive Behaviors, 35(2), 73-83. doi: 10.1016/j.addbeh.2009.09.013

Capaldi, D. M., Tiberio, S. S., Kerr, D. C., \& Pears, K. C. (2016). The relationships of parental alcohol versus tobacco and marijuana use with early adolescent onset of alcohol use. Journal of Studies on Alcohol and Drugs, 77(1), 95-103. doi: $10.15288 / \mathrm{jsad} .2016 .77 .95$

Casswell, S., Pledger, M., \& Pratap, S. (2002). Trajectories of drinking from 18 to 26 years: identification and prediction. Addiction, 97(11), 1427-1437. doi: 10.1046/j.1360-0443.2002.00220.x

Cortes, R. C., Fleming, C. B., Mason, W. A., \& Catalano, R. F. (2009). Risk factors linking maternal depressed mood to growth in adolescent substance use. Journal of Emotional and Behavioral Disorders, 17(1), 49-64. doi: $10.1177 / 1063426608321690$

Donovan, J. E., \& Molina, B. S. (2011). Childhood risk factors for early-onset drinking. Journal of Studies on Alcohol and Drugs, 72(5), 741-751. doi: 10.15288/jsad.2011.72.741

El-Sheikh, M., \& Flanagan, E. (2001). Parental problem drinking and children's adjustment: Family conflict and parental depression as mediators and moderators of risk. Journal of Abnormal Child Psychology, 29(5), 417-432. doi: 10.1023/A:1010447503252

Emshoff, J., \& Price, A. (1999) Prevention and intervention strategies with children of alcoholics. Pediatrics, 103(Sup 2), 1112-1121. doi: 10.1542/peds.103.S2.1112

Fernández, V., \& Corral, I. (2018). Consumo de alcohol y género: diferencias desde la perspectiva de los profesionales de enfermería. Nure Investigación, 15, 96.

García-Barba, M., Giménez-García, C., Castro-Calvo, J., Nebot-García, J. E., \& Ballester-Arnal, R. (2018). ¿Existe relación entre el consumo de alcohol de los padres y el de los adolescentes? Revista INFAD de Psicología. International Journal of Developmental and Educational Psychology, 2(1), 229-238. doi: 10.17060/ijodaep.2018.n1.v2.1216

Guo, J., Hawkins, J. D., Hill, K. G., \& Abbott, R. D. (2001). Childhood and adolescent predictors of alcohol abuse and dependence in young adulthood. Journal of Studies on Alcohol, 62(6), 754-762.

Gómez, J. (2006). El alcoholismo femenino, una verdad oculta. Trastornos Adictivos, 8(4), 251-260. doi: 10.1016/S1575-0973(06)75131-5

Handley, E. D., \& Chassin, L. (2009). Intergenerational transmission of alcohol expectancies in a high-risk sample. Journal of Studies on Alcohol and Drugs, 70(5), 675-682. doi: 10.15288/jsad.2009.70.675

Harrison, L. D., \& Hughes, A. (1997). The validity of self-reported drug use: Improving the accuracy of survey estimates. NIDA Research Monograph 167. US Department of Health and Human Services, National Institutes of Health, National Institute on Drug Abuse, Division of Epidemiology and Prevention Research.

Haugland, S. H., Holmen, T. L., Ravndal, E., \& Bratberg, G. H. (2013). Parental alcohol misuse and hazardous drinking among offspring in a general teenage population: gender-specific findings from the Young-HUNT 3 study. BMC Public Health, 13(1), 1140. doi: 10.1186/1471-2458-13-1140

Hernández, E. (2014). Historia familiar de consumo de alcohol y el consumo de alcohol en adolescentes de secundaria (Doctoral dissertation). Universidad Autónoma de Nuevo León.

Huxley, A., \& Foulger, S. (2008). Parents who misuse substances: Implications for parenting practices and treatment seeking behaviour. Drugs and Alcohol Today, 8(3), 9-16. doi: 10.1108/17459265200800020

Jester, J. M., Jacobson, S. W., Sokol, R. J., Tuttle, B. S., \& Jacobson, J. L. (2000). The influence of maternal drinking and drug use on the quality of the home environment of school-aged children. Alcoholism: Clinical and Experimental Research, 24(8), 1187-1197. doi: 10.1111/j.1530-0277.2000.tb02082.x

Kovacs, F. M., Gestoso García, M., Oliver-Frontera, M., Gil del Real Calvo, M. T., López Sánchez, J., Mufraggi Vecchierini, N., \& Palou Sampol, P. (2008). La influencia de los padres sobre el consumo de alcohol y tabaco y otros hábitos 
de los adolescentes de Palma de Mallorca en 2003. Revista Española de Salud Pública, 82(6), 677-689.

Lam, W., \& O'Farrell, T. J. (2011). Dynamics of substance-abusing families and implications for treatment. In S. L. A. Straussner \& C. H. Fewell, Editors. Children of substance abusing parents: dynamics and treatment (pp. 49-75). New York, NY: Springer.

Latendresse, S. J., Rose, R. J., Viken, R. J., Pulkkinen, L., Kaprio, J., \& Dick, D. M. (2008). Parenting mechanisms in links between parents' and adolescents' alcohol use behaviors. Alcoholism: Clinical and Experimental Research, 32(2), 322-330. doi: 10.1111/j.1530-0277.2007.00583.x

Lieb, R., Merikangas, K. R., Höfler, M., Pfister, H., Isensee, B., \& Wittchen, H. U. (2002). Parental alcohol use disorders and alcohol use and disorders in offspring: a community study. Psychological Medicine, 32(1), 63-78. doi: 10.1017/s0033291701004883

MacLeod, J., Hickman, M., Bowen, E., Alati, R., Tilling, K., \& Smith, G. D. (2008). Parental drug use, early adversities, later childhood problems and children's use of tobacco and alcohol at age 10: birth cohort study. Addiction, 103(10), 17311743. doi: 10.1111/j.1360-0443.2008.02301.x

Maldonado, M. M., Reingle, J. M., Delcher, C., \& Branchini, J. (2011). The role of parental alcohol consumption on driving under the influence of alcohol: Results from a longitudinal, nationally representative sample. Accident Analysis \& Prevention, 43(6), 2182-2187. doi: 10.1016/j.aap.2011.06.012

Manning, V. (2011) Estimates of the Number of Infants (Under the Age of One Year) Living with Substance Misusing Parents. London: NSPCC.

Mares, S. H., van der Vorst, H., Engels, R. C., \& Lichtwarck-Aschoff, A. (2011). Parental alcohol use, alcohol-related problems, and alcohol-specific attitudes, alcohol-specific communication, and adolescent excessive alcohol use and alcohol-related problems: An indirect path model. Addictive Behaviors, 36(3), 209-216. doi: 10.1016/j.addbeh.2010.10.013

McManus, S., Bebbington, P. E., Jenkins, R., \& Brugha, T. (2016). Mental Health and Wellbeing in England: Adult Psychiatric Morbidity Survey 2014. NHS digital.

Medina-Mora, M. E., Gómez-Mont, F., \& Campillo, C. (1981). Validity and reliability of a high school drug use questionnaire among Mexican students. Bulletin on Narcotics, 33(4), 67-76.

Medina-Mora, M. E., Real, T., Villatoro, J., \& Natera, G. (2013). Las drogas y la salud pública: ¿hacia dónde vamos? Salud Pública de México, 55(1), 67-73.

Meyers, J. L., Shmulewitz, D., Elliott, J. C., Thompson, R. G., Aharonovich, E., Spivak, B., ... Hasin, D. S. (2014). Parental alcohol history differentially predicts offspring disorders in distinct subgroups in Israel. Journal of Studies on Alcohol and Drugs, 75(5), 859-869. doi: 10.15288/jsad.2014.75.859

Murphy, E., O’Sullivan, I., O’Donovan, D., Hope, A., \& Davoren, M. P. (2016). The association between parental attitudes and alcohol consumption and adolescent alcohol consumption in Southern Ireland: a cross-sectional study. BMC Public Health, 16(1), 821-828. doi: 10.1186/s12889-016-3504-0

Natera-Rey, G., Borges, G., Medina-Mora, M. E., Solís-Rojas, L., \& Tiburcio-Sainz, M. (2001). La influencia de la historia familiar de consumo de alcohol en hombres y mujeres. Salud Pública de México, 43(1), 17-26.

Ohannessian, C. M. (2012). Parental Problem Drinking and Adolescent Psychosocial Adjustment: The Mediating Role of Adolescent-Parent Communication. Journal of Research on Adolescence, 22(3), 498-511. doi: 10.1111/j.15327795.2012.00791.x

Oshi, S. N., Abel, W. D., Oshi, D. C., Whitehorne-Smith, P., Ricketts-Roomes, T. F., Meka, I. A., ... Agu, C. F. (2018). Parental alcohol drinking habit as a predictor of alcohol use among secondary school students in Barbados. Asian Pacific Journal of Cancer Prevention, 19(S1), 57-62. doi: 10.22034/APJCP.2018.19. $\mathrm{S} 1.57$

Pedersen, W., \& von Soest, T. (2013). Socialization to binge drinking: A populationbased, longitudinal study with emphasis on parental influences. Drug and Alcohol Dependence, 133(2), 587-592. doi: 10.1016/j.drugalcdep.2013.07.028

Poelen, E. A., Engels, R. C., Scholte, R. H., Boomsma, D. I., \& Willemsen, G. (2009). Predictors of problem drinking in adolescence and young adulthood. European Child \& Adolescent Psychiatry, 18(6), 345-352. doi: 10.1007/s00787-0090736-X

Poelen, E. A., Scholte, R. H., Willemsen, G., Boomsma, D. I., \& Engels, R. C. (2007). Drinking by parents, siblings, and friends as predictors of regular alcohol use in adolescents and young adults: a longitudinal twin-family study. Alcohol and Alcoholism, 42(4), 362-369. doi: 10.1093/alcalc/agm042

Ramírez, A. S., Naal, A. R., Salinas, E. K., \& Pérez, C. A. (2014). Una visión del alcoholismo del padre desde la mirada de los hijos. Salud y Drogas, 14(2), 109120.

Rognmo, K., Torvik, F. A., Ask, H., Røysamb, E., \& Tambs, K. (2012). Paternal and maternal alcohol abuse and offspring mental distress in the general population: the Nord-Trøndelag health study. BMC Public Health, 12(1), 1-12. doi: 10.1186/1471-2458-12-448

Rossow, I., Keating, P., Felix, L., \& McCambridge, J. (2016). Does parental drinking influence children's drinking? A systematic review of prospective cohort studies. Addiction, 111(2), 204-217. doi: 10.1111/add.13097

Slutske, W. S., D’Onofrio, B. M., Turkheimer, E., Emery, R. E., Harden, K. P., Heath, A. C., \& Martin, N. G. (2008). Searching for an environmental effect of parental alcoholism on offspring alcohol use disorder: A genetically informed study of children of alcoholics. Journal of Abnormal Psychology, 117(3), 534-551. doi: 10.1037/a0012907

Suárez, C., Del Moral, G., Martínez, B., John, B., \& Musitu, G. (2016). El patrón de consumo de alcohol en adultos desde la perspectiva de los adolescentes. Gaceta Sanitaria, 30(1), 11-17. doi: 10.1016/j.gaceta.2015.06.004

Telumbre, J., López, M., Sánchez, A., Magnolia-Araujo, F., \& Torres, M. (2017). Relación de la Historia Familiar de Consumo de Alcohol y Consumo de Alcohol de los Adolescentes. RqR Enfermería Comunitaria, 5(1), 15-26. Retrieved from https://dialnet.unirioja.es/servlet/articulo?codigo $=5858771$

Torvik, F. A., Rognmo, K., Ask, H., Røysamb, E., \& Tambs, K. (2011). Parental alcohol use and adolescent school adjustment in the general population: Results from the HUNT study. BMC Public Health, 11(1), 706. doi: 10.1186/14712458-11-706

Villatoro, J., Fregoso, D., Bustos, M., Oliva, N., Mujica, A., Martín del Campo, R., ... Medina-Mora, M. E. (2015). Encuesta Nacional de Consumo de Alcohol en Estudiantes 2014: Reporte de Alcohol. México: Instituto Nacional de Psiquiatría Ramón de la Fuente Muñiz, Comisión Nacional Contra las Adicciones, Secretaría de Salud.

Voogt, C., Beusink, M., Kleinjan, M., Otten, R., Engels, R., Smit, K., \& Kuntsche, E. (2017). Alcohol-related cognitions in children (aged 2-10) and how they are shaped by parental alcohol use: A systematic review. Drug and Alcohol Dependence, 177, 277-290. doi: 10.1016/j.drugalcdep.2017.04.006

Yap, M. B., Cheong, T. W., Zaravinos-Tsakos, F., Lubman, D. I., \& Jorm, A. F. (2017). Modifiable parenting factors associated with adolescent alcohol misuse: a systematic review and meta-analysis of longitudinal studies. Addiction, 112(7), 1142-1162. doi: 10.1111/add.13785 